\title{
PEMBAHARUAN CRIMINAL POLICY TENTANG SISTEM PERTANGGUNGJAWABAN PIDANA KORPORASI (Upaya Strategis dalam Penaggulangan Kejahatan Korporasi)
}

\author{
Oleh : \\ Zulkarnain $^{\star}$, Zahir Rusyad $^{\star *}$
}

\begin{abstract}
Corporation crime is as extra ordinary crime we should fight against seriously. Great efforts must be made in order to remove this crime. Such effortst, however, are not in a direct proportion with the criminal policy serving as a base in its law enforcement. The criminal codes serving as the main legal law turn out just considering natural people as a subject of criminal law that may be criminaly assumed, instead of recognizing corporations as the subject of the criminal law, although in some corporation arrangements out of the criminal codes, there are some schemas that recognize corporations as a subject of law. Such arrangements, however are still doubtfully made, since the recognition of corporations as a subject of law in the law still denies the responsibility and comdemnation of corporation in the Indonesian criminal law still refer to a paradigm that position a person as a doer of crimes. As a result, although it is clear that the actor of crimes is a corporation, it is the natural person who should be responsible for the crime.
\end{abstract}

Kata Kunci: korporasi, pertanggungjawaban pidana.

\section{PENDAHULUAN}

Perkembangan kejahatan seiring dengan pertumbuhan korporasi yang semakin pesat dalam bidang kegiatan ekonomi, muncul apa yang disebut dengan kejahatan korporasi. ${ }^{1}$ Kejahatan korporasi merupakan extra ordinary crime. Bahkan dampaknya tidak hanya kerugian sesaat, tetapi berdampak dalam waktu yang sangat lama. Oleh karena itu, gagasan pemidanaan korporasi melalui kebijakan pidana semakin menguat. ${ }^{2}$

\footnotetext{
'Zulkarnain adalah Dosen pada Fakultas Hukum Universitas Widyagama Malang

1 Arief Amrullah, Politik Hukum Pidana dalam Rangka Perlindungan Korban Kejahatan Ekonomi di Bidang Perbankan, Bayumedia Publishing, Malang, 2003, hal. 1

2 Susanto, I.S. 1998. Tinjauan Kriminologis tentang Kejahatan Ekonomi, Makalah pada Penataran Hukum Pidana dan Kriminologi, UNDIP, Semarang 23-30 Nopember 1998, hal. 5
}

Diakuinya korporasi sebagai subyek hukum pidana, berarti korporasi dapat dipertanggungjawabkan. Hal ini juga berarti bahwa baik di kalangan akademisi maupun praktisi, kejahatan khusus yang disebut corporate crime tersebut dianggap sebagai kejahatan yang pelakunya (korporasi) bisa dipertanggungjawabkan dalam hukum pidana. ${ }^{3}$

Namun, ternyata KUHP sebagai induk hukum pidana materiil tidak mengatur korporasi sebagai subyek hukum pidana. Sehingga penegakan hukum terhadap kehatan korporasi masih jauh dari yang diharapkan. Melihat kelemahan yuridis dari KUHP tersebut, di Indonesia dewasa ini sedang

\footnotetext{
s Munir Fuady, Bisnis Kotor: Anatomi Kejahatan Kerah Putih, Citra Aditya Bakti, Bandung, 2004, hal. 27
} 
berlangsung usaha untuk memperbaharui KUHP, termasuk usaha untuk memformu-lasikan kebijakan hukum pidana tentang penanggulangan kejahatan korporasi.

Meskipun beberapa peraturan hukum pidana di luar KUHP mengatur kejahatan korporasi (mengakui korporasi sebagai subyek tindak pidana), namun sistem pertanggaung jawabannya tidak diatur secara tegas. Dengan demikian, maka secara hukum harus dikembalikan pada ketentuan KUHP yang secara jelas tidak mengakui korporasi sebagai subyek tindak pidana.

Oleh karena itu, perlu ada upaya untuk memperbaharui kebijakan hukum pidana tentang sistem pertanggungjawaban pidana korporasi yang dilandasi oleh kajian teoritik-empirik dalam rangka menanggulangi kejahatan korporasi di Indonesia. Salah satu upaya tersebut adalah dengan melakukan serangkaian penelitian dan kajian ilmiah tentang seluk beluk kejahatan korporasi dan sistem pertanggungjawabannya, sebagai pijakan penyusunan naskah akademik untuk pembaharuan formulasi kebijakan hukum pidana nasional.

Penelitian yang dilakukan penulis ini berawal dari keprihatinan penulis atas lemahnya kebijakan hukum pidana tentang corporate crime di Indonesia. Berbagai permasalahan yang. kemudian menjadi fokus dari penelitian ini terumuskan dalam beberapa hal, yaitu: Bagaimana pengaturan sistem pertanggungjawaban pidana korporasi dalam hukum pidana positif dan bagaimana fakta empirik yang mempengaruhi efektivitas penegakan hukumnya? Apa saja faktor-faktor kriminogen dari kejahatan korporasi? Bagaimana pula perumusan criminal policy yang berbasis pada alasan kriminologis? inilah yang akan dikaji dalam tulisan ini.

\section{METODE PENELITIAN}

Penelitian ini dilakukan dengan menggabungkan dua model penelitian yan dikenal dalam penelitian hukum, yaitu penelitian hukum normatif (normative legal research) dan penelitian hukum empirik (empirical legal research). Penelitian ini sedianya akan dilakukan di beberapa kota besar (10 kota dan kabupaten) di Jawa Timur, namun karena beberapa kendala teknis, maka penelitian ini difokuskan pada beberapa kota di Malang Raya saja sebagai sampel penelitian. Sebagai key informan dalam penelitian ini tentu saja adalah Jaksa Pidana Khusus Kejaksaan Negeri, Hakim di Pengadilan Negeri, dan beberapa praktisi dan akademisi hukum. Sebagai penelitian yang mengkaji bekerjanya hukum pidana di masyarakat dan penafsiran hukum secara sistematis, maka tentu saja penelitian ini diarahkan sebagai penelitian kualitatif (qualitative legal research).

\section{HASIL DAN PEMBAHASAN}

\section{A. Korporasi dan Kejahatan Korporasi}

Korporasi merupakan istilah yang biasa digunakan oleh para ahli hukum pidana dan kriminologi untuk menyebut apa yang dalam bidang hukum lain (khususnya dalam bidang hukum perdata) disebut badan hukum (recht persoon). Satjipto Rahardjo memberikan definisi bahwa korporasi adalah suatu badan hasil ciptaan hukum. ${ }^{4}$ Badan yang diciptakannya tersebut terdiri dari "corpus", yaitu struktur fisiknya dan ke dalamnya hukum memasukkan unsur "animus" yang membuat badan itu mempunyai kepribadian. Oleh karena badan hukum itu merupakan ciptaan hukum, maka kecuali penciptaannya, kematiannya pun juga ditentukan oleh hukum.

Sedangkan kejahatan korporasi, Simpson

4 Satjipto Rahardjo, Ilmu Hukum, Alumni, Bandung, 1986, hal 110 
menyatakan "corporate crime is a type of white-collar crime". Simpson, kemudian mengutip pendapat John Braithwaite, yang mendefinisikan kejahatan korporasi sebagai "conduct of a corporation, or employees acting on behalf of a corporation, which is proscribed and punishable by law" Clinard dan Yeager, memberikan pengertian bahwa " $a$ corporate crime is any act committed by corporation that is punished by the state, regadless of whether it is punished under administrative, civil, or criminal law". 5

Pada mulanya, subyek hukum pidana hanya naturlijke persoon, sedangkan korporasi/ recht persoon tidak diakui sebagai subyek hukum pidana. Hal ini karena diberlakukannya asas universtas delinquere non potest. ${ }^{6}$ Namun, Senoaji berpendapat bahwa kemungkinan adanya pemidanaan terhadap korporasi didasarkan tidak saja atas pertimbangan utilitas, melainkan pula atas dasar teoritis juga dibenarkan. ${ }^{7}$

Dijadikannya korporasi sebagai subyek hukum pidana bukanlah hal baru, sebab sejak dahulu menurut Maine, korporasi sudah menjadi subyek hukum pidana. Bahkan di Indonesia dahulu desa sebagai korporasi juga dikenai pidana denda. Mereka yang menolak korporasi sebagai subyek hukum pidana, karena berpendirian bahwa korporasi adalah "persona ficta", dapat dibenarkan. Namun, apabila diperhatikan dalam kehidupan sosial ekonomi, maka gerak-gerik korporasi tersebut harus dikendalikan oleh hukum, dan apabila menyimpang, maka korporasi dapat

5 dalam Weda, Made Darma. 1993. Beberapa Catatan tentang Kejahatan Korporasi, Makalah pada Seminar Nasional Viktimologi III, Fakultas Hukum Universitas Airlangga Surabaya, 20-21 Desember 1993, hal 3

6 (Wirjono Prodjodikoro, Azas-azas Hukum Pidana Indonesia, Eresco, Bandung, 1986, hal. 55

${ }^{7}$ Setiyono, Kejahatan Korporasi, Bayumedia Publishing, Malang, 2003, hal. 11 dipertanggungjawabkan.

\section{B. Sistem Pertanggungjawaban Pidana Korporasi}

Pertanggungjawaban pidana lahir dengan diteruskannya celaan (verwijbaarheid) yang obyektif terhadap perbuatan yang dinyatakan sebagai tindak pidana berdasarkan hukum pidana yang berlaku, dan secara subyektif kepada pelaku yang memenuhi persayaratan untuk dapat dikenakan pidana karena perbuatannya itu. ${ }^{8}$

Hal itu didasarkan pada asas "actus non facit reum nisi mens sit rea", orang tersebut akan dipidana apabila dia mempunyai kesalahan. ${ }^{9}$ Lebih lanjut Sudarto menyatakan bahwa:

"Dipidananya seseorang tidaklah cukup apabila orang itu telah melakukan perbuatan yang bertentangan dengan hukum atau bersifat melawan hukum. Jadi meskipun perbuatan tersebut memenuhi rumusan delik dalam undang-undang, namun untuk pemidanaan masih perlu adanya syarat untuk menjatuhkan pidana, bahwa orang yang melakukan perbuatan itu mempunyai kesalahan atau bersalah (subjective guilt)."10

Jadi pertanggungjawaban pidana berbicara kesalahan dalam hukum pidana.

\footnotetext{
8, Dwidja Priyatno Kebijakan Legislasi tentang Sistem Pertanggungjawaban Pidana Korporasi di Indonesia, CV. Utomo, Bandung, 2004, hal. 30

${ }^{9}$ Ramelan, Pertanggungjawaban Korporasi dalam Hukum Pidana, Makalah pada Seminar Nasional tentang Aspek Pertanggungjawaban Pidana dalam Kebijakan Publik dari Tindak Pidana Korupsi, Kejaksaan Agung RI dan FH UNDIP, Semarang 6-7 Mei 2004, hal. 6

10 Sudarto Hukum Pidana 1, Badan Penyediaan Bahan-bahan Kuliah UNDIP, Semarang, 1988. hal. 85 11 Saleh, Roeslan. 1983. Perbuatan Pidana dan Pertanggungjawaban Pidana: Dua Pengertian Dasar dalam Hukum Pidana, Aksara Baru, Jakarta, 1983, hal. 77-78
} 
Adanya kesalahan menjadi yang pertama untuk dicari. Roeslan Saleh ${ }^{11}$ sependapat dengan Moeljatno ${ }^{12}$ bahwa mampu bertanggungjawab, kesengajaan, kealpaan, serta tidak adanya alasan pemaaf, merupakan unsur-unsur kesalahan.

S. Titus Reid juga menulis bahwa "the law requires criminal intent, or mens rea, the element required to establish culpability. This element is extremely important, for in many cases it will be the critical factor in determining whether and act was or was not a crime. "13

\section{Sebagaimana hal di atas,} pertanggungjawaban pidana sangat bergantung pada kesalahan (liability based on fault). Namun, pertanggungjawaban pidana bagi korporasi sedikit ada penyimpangan dari teori pertanggungjawaban pidana pada umumnya. Unsur "kesalahan" dalam kejahatan korporasi tidak lah mutlak diberlakukan, meskipun adanya kesalahan harus tetap diperhatikan.

Dalam hal ini, dikenal doktrin strict liability, di mana apabila seseorang (korporasi) menjalankan jenis kegiatan yang dapat digolongkan sebagai extrahazardous atau $a b$ normally dangerous, maka ia wajib bertanggungjawab walaupun ia sudah bertindak hati-hati. ${ }^{14}$ Mengenai hal ini, banyak sependapat dengan Muladi dan Priyatno bahwa:

"Dalam masalah pertanggung jawaban

\footnotetext{
${ }^{12}$ Moeljatno, berpendapat bahwa untuk adanya kesalahan harus dipikirkan dua hal di samping melakukan perbuatan pidana, yaitu: (1) adanya keadaan psychis (bathin) yang tertentu, dan (2) adanya hubungan yang tertentu antara keadaan bathin tersebut dengan perbuatan yang dilakukan, hingga menimbulkan celaan. Lihat kembali Ramelan (2004:6)

${ }^{13}$ Reid, S.T. 1985. Crime and Criminology, Hola, Reindard \& Winston, 1985, hal. 7

${ }^{14}$ Mas Ahmad Santosa, Penerapan Asas Tanggung Jawab Mutlak (Strict Liablity) di Bidang Lingkungan Hidup, Indonesia Center for Environmental Law (ICEL), Jakarta, 1998, hal. 3
}

pidana, asas kesalahan masih tetap dipertahankan, tetapi dalam perkembangan di bidang hukum, khususnya hukum pidana yang menyangkut pertanggung jawaban pidana korporasi, asas kesalahan atau "asas tidak ada pidana tanpa kesalahan" tidak mutlak berlaku. Cukuplah fakta yang menderitakan si korban dijadikan dasar untuk menuntut pertanggungjawaban pidana pada si pelaku sesuai dengan adagium "res ipsa loquitur", bahwa fakta sudah berbicara sendiri." 15

Hamzah Hatrik ${ }^{16}$ juga menilai bahwa dalam pertanggungjawaban korporasi, si pembuat sudah dapat dipidana jika ia telah melakukan perbuatan yang dilarang sebagaimana telah dirumuskan dalam undangundang tanpa melihat lebih jauh sikap batin dari si pelaku (korporasi) tersebut. Oleh karena sangat sulit dalam mencari kesalahan pada korporasi, maka pemberlakuan pertanggungjawaban pidana tanpa kesalahan (liability without fault) sangat diperlukan dalam pertanggungjawaban pidana korporasi.

Doktir dalam Teori Pertanggung jawaban Korporasi

Dalam teori pertanggung jawaban pidana korporasi, awalnya dikenal ada dua macam doktrin yaitu doktrin strict liability dan doktrin vicarious liability. Namun karena tetap harus mempertimbangkan unsur kesalahan, maka sebagaimana dijelaskan oleh Muladi, ${ }^{17}$ muncul teori baru yang diperkenalkan oleh Haldane yaitu "Theory of primary corporate

\footnotetext{
${ }^{15}$ Priyatno, Dwija. 1991. Suatu Tinjauan Terhadap Pertanggungjawaban Korporasi dalam Hukum Pidana dan Prospeknya, Tesis Program Pascasarjana UNDIP, Semarang, 1991, hal. 87

16 Hamzah Hatrik, Asas Pertanggung jawaban Korporasi dai hokum Pidana Indonesia: Strict Liablity dan Vicarious Liability, Raja Grafindo Persada, Jakarta, 1996, hal. 110
} 
criminal liability" yang terkenal dengan "Identification Theory".

\section{Doktrin Identification Theory}

Doktrin ini memandang bahwa perbuatan/delik dan kesalahan/sikap batin pejabat senior dipandang sebagai perbuatan dan sikap batin perusahaan. Unsur-unsur tindak pidana dapat dikumpulkan dari perbuatan dan sikap batin pejabat senior (Priyatno, 2004:90, Gillies 1990:133). Atas dasar teori identifikasi ini, maka semua tindakan yang dilakukan oleh orang-orang yang dapat diidentifikasikan dengan korporasi atau mereka yang disebut "who constitute its directing mind will of the corporation", dapat diidentifikasikan sebagai perbuatan atau tindak pidana yang dilakukan oleh korporasi. Dengan demikian, pertanggungjawaban korporasi tidak didasarkan atas konsep pertanggungjawaban pengganti (vicarious liability).

\section{Doktrin Vicarious Liability}

Vicarious liability dapat diartikan bahwa seseorang yang tidak memiliki kesalahan pribadi, bertanggungjawab atas tndakan orang lain (pertanggungjawaban pengganti). Pertanggungjawaban seperti ini hampir semuanya ditujukan pada delik dalam undangundang (statutory offences). Menurut Barda N. Arief, vicarious liability adalah pertanggungjawaban hukum seseorang atas perbuatan salah yang dilakukan oleh orang lain (the legal resposibility of one person for the wrongful acts of another). Menurut doktrin ini, majikan (employer) adalah penanggungjawab utama dari perbuatan para buruh/karyawan yang melakukan perbuatan itu dalam ruang lingkup tugas/pekerjaannya. Hal itu didasarkan pada

${ }^{17}$ Muladi. Pertangungjawaban Korporasi dalam Hukum Pidana (Corporate Criminal Liability), Makalah pada Seminar Aspek Pertanggungjawaban Pidana dalam Kebijakan Publik dari Tindak Pidana Korupsi, FH UNDIP, Semarang 6-7 Mei 2004, hal. 6 "employment principle" yang menyatakan "the servant's act is the master 's act in law". ${ }^{18}$

\section{Doktrin Strict Liability}

Dalam doktrin strict liability, pertanggungjawaban tidak harus mempertimbangkan adanya kesalahan. Karena dalam pertanggung jawaban korporasi, kesalahan tidaklah mutlak berlaku. Seseorang/ korporasi sudah dapat dipertanggungjawabkan walaupun pada diri orang tersebut tidak ada kesalahan. ${ }^{19}$ Sedangkan menurut Romli Atmasasmita ${ }^{20}$ doktrin ini tidak mensyaratkan adanya mens rea atau kesalahan dari si pembuatnya.

Model-model Sistem Pertanggung jawaban Pidana Korporasi

Model pertanggungjawaban jawaban pidana korporasi tidak lepas dari dua subyek hukum pidana dalam kejahatan korporasi, yaitu orang sebagai pengurus dan korporasi itu sendiri. Sehingga terkait dengan kedudukan korporasi dan sifat pertanggungjawaban pidana korporasi dalam kejahatan korporasi, terdapat tiga model pertanggungjawaban pidana korporasi, yaitu:

1. Pengurus sebagai pembuat dan penguruslah yang bertanggungjawab;

2. Korporasi sebagai pembuat, dan penguruslah yang bertanggungjawab;

3. Korporasi sebagai pembuat dan juga sebagai yang bertanggungjawab. ${ }^{21}$

Pada model pertama, korporasi tidak bisa dipersalahkan atas perbuatan tercela dari

${ }^{18}$ Barda Nawawi Arief, Bunga Rampai Kebijakan Hukum Pidana, Citra Aditya Bakti, Bandung, 1996, hal. 236

${ }^{19}$ Ramelan, Op. Cit. Hal. 12

20 Romli Atmasasmita, Perbandingan Hukum Pidana, Mandar Maju, Bandung, 2000, hal. 79

${ }^{21}$ Mardjono Reksodiputro, Hak Asasi Manusia dalam Sistem Peradilan Pidana, Pusat Pelayanan Keadilan dan Pengabdian Hukum, Universitas Indonesia, Jakarta, 1994 hal. 72; lihat juga Muladi dan 
pengurus atau karyawannya. Bahwa suatu perbuatan pidana hanya dapat dilakukan oleh perorangan. Pemikiran fiksi tidak berlaku pada lapangan hukum pidana, sesuai Pasal 392 KUHP. ${ }^{22}$

Sementara pada model kedua, Sifat perbuatan yang menjadikan tindak pidana itu adalah "onpersoonlijk". Orang yang memimpin korporasi bertanggungjawab pidana, terlepas apakah ia tahu atau tidak tentang dilakukannya perbuatan itu. Model ini sudah tidak mempertimbangkan adanya asas mens rea.

Sedangkan model ketiga, memandang bahwa ditetapkannya pengurus saja sebagai yang dapat dipidana dalam pertanggungjawaban korporasi ternyata tidak cukup. Oleh karena itu, dimungkinkan pula untuk memidana korporasi dan pengurus sekaligus. Hal itu selaras dengan Pasal 15 UU Nomor 7 Drt. Tahun 1955. Model ini membenarkan bahwa korporasi sebagai pelaku tindak pidana dan dapat dipertanggungjawabkan. Hal itu didasarkan atas dasar falsafah integralistik, (keseimbangan, keselarasan dan keserasian antara kepentingan individu dan kepentingan sosial); atas dasar asas kekeluargaan; untuk memberantas anomie of succes; untuk perlindungan konsumen; dan untuk kemajuan teknologi.

\section{Pengaturan Korporasi dalam Hukum}

Priyatno, Pertanggung jawaban Korporasi dalam Hukum Pidana, Sekolah Tinggi Ilmu Hukum Bandung, Bandung, 1999, hal. 67-68).

22 Schaffmeister dkk, Hukum Pidana, Editor Terjemahan J.E. Sahetapy, Konsorsium Ilmu Hukum Departemen Pendidikan dan Kebudayaan dan Liberty, Yogyakarta, 1995, hal. 272-273).

\section{Pidana Positif Indonesia}

Hukum pidana positif dalam kajian keilmuan hukum pidana dimaksudkan adalah setiap peraturan perundang-undangan pidana yang dinyatakan berlaku atau diberlakukan pada saat ini. Oleh karena itu, maka yang dimaksud dengan hukum pidana positif Indonesia adalah Kitab Undang-undang Hukum Pidana (KUHP) yang diberlakukan berdasarkan Undang-undang Nomor 1 Tahun 1946 beserta beberapa perubahan-perubahannya, dan setiap peraturan perundangundangan pidana yang diberlakukan secara khusus di luar KUHP.

Prinsip dasar atau prinsip umum yang harus diperhatikan dalam pengaturan pidana dan pemidanaan adalah bahwa setiap perumusan ketentuan pidana harus tetap berada dalam sistem hukum pidana materiel (sistem pemidanaan substantif) yang berlaku saat ini. Sebagaimana dimaklumi, sistem hukum pidana substantif yang berlaku saat ini adalah sebagai berikut :

1. Sistem hukum pidana materiel terdiri dari keseluruhan sistem peraturan perundangundangan ("statutory rules") yang ada di dalam KUHP (sebagai induk aturan umum) dan UU khusus di luar KUHP.

2. Keseluruhan peraturan perundangundangan ("statutory rules") di bidang hukum pidana substantif itu, terdiri dari "aturan umum" ("gene-ral rules") dan "aturan khusus" ("special rules").

3. Aturan umum terdapat di dalam KUHP (Buku I), dan aturan khusus terdapat di dalam KUHP (Buku II dan III) maupun dalam UU Khusus di luar KUHP. Aturan khusus ini pada umumnya memuat perumusan tindak pidana tertentu, namun dapat pula memuat aturan khusus yang menyimpang dari aturan umum.

Dengan demikian, sistem hukum pidana 
substantif yang berlaku saat ini dapat digambarkan bahwa ketentuan pidana dalam UU khusus di luar KUHP merupakan subsistem dari keseluruhan sistem hukum pidana.

Sebagai sub-sistem, UU khusus terikat pada ketentuan umum yang ada di dalam KUHP (Buku I). Namun patut dicatat, bahwa ketentuan umum KUHP "yang mengikat (yang berlaku)" untuk UU khusus, hanyalah Bab I s/ d VIII (Pasal 1 s/d 85) Buku I KUHP, sepanjang UU khusus tidak membuat ketentuan lain yang menyimpang (Lihat Pasal 103 KUHP). Ketentuan umum dalam Bab IX Buku I KUHP (Pasal 86 s/d 102) hanya berlaku untuk KUHP, tidak untuk UU khusus di luar KUHP. Agar ada harmonisasi dan kesatuan sistem yang demikian, maka bagi setiap perancang UU khusus harus memahami dan menguasai keseluruhan sistem aturan umum dalam Buku I KUHP. Apabila tidak, akan timbul masalah juridis.

Dari hasil penelitian secara normatif terhadap sistem dan subsistem hukum pidana, ditemukan fakta hukum bahwa KUHP yang menjadi induk dari setiap perundang-undangan pidana ternyata memang tidak mengatur tentang korporasi sebagai subyek hukum pidana. Rumusan pasal-pasal yang banyak mengunakan frasa "Barang siapa....", "Setiap orang....", "Seorang ibu ...." dan lain-lain menunjukkan bahwa KUHP hanya mengakui naturlijke persoon atau orang alamiah (manusia) sebagai subyek hukum pidana. Sementara korporasi atau badan hukum sama sekali tidak diakui sebagai subyek hukum pidana dalam KUHP. Meskipun terdapat ketentuan sebagaimana diatur dalam Pasal 59 yang menyatakan bahwa "Dalam hal menentukan hukuman karena pelanggaran, maka terhadap pengurus, anggota salah satu pengurus atau komisaris, maka hukuman tidak dijatuhkan atas pengurus atau komisaris, jika nyata bahwa pelanggaran tersebut telah terjadi di luar tanggungannya." Walaupun ketentuan ini hanya berlaku untuk tindak pidana pelanggaran, tetapi jelas hal itu dapat disimpulkan bahwa KUHP tidak mengakui korporasi sebagai subyek yang bisa dikenai sanksi pidana.

Namun apabila dilihat papa ketentuan undang-undang di luar KUHP, maka ditemukan beberapa ketentuan yang mengatur tentang korporasi. Dari sekian banyak ketentuan yang ada, dapat dikelompokkan dalam tiga model pengaturan:

1. menentukan korporasi sebagai subyek hukum pidana tetapi tanggungjawab pidana-nya tetap dibebankan kepada orang sebagai subyek hukum pidana;

2. menentukan korporasi sebagai subyek hukum pidana dan membebankan tanggungjawab pidana kepada korporasi;

3. menentukan korporasi sebagai subyek hukum pidana dan membebankan tanggungjawab pidana kepada korporasi, sekaligus mengancam korporasi dengan pidana perampasan kemerdekaan.

Pada kelompok pertama, terdapat beberapa peraturan perundang-undangan pidana yang mengatur demikian, diantaranya adalah Undang-undang Nomor 22 Tahun 1957 tentang Penyelesaian Perselisihan Perburuhan. Undang-undang ini menentukan dalam Pasal 27 ayat (1) bahwa "Jika sesuatu hal yang diancam dengan hukuman dalam undangundang ini dilakukan oleh suatu badan hukum atau perserikatan, maka tuntutan ditujukan serta hukuman dijatuhkan terhadap pengurus atau pimpinan badan hukum atau perserikatan itu." Katentuan senada juga terdapat dalam beberapa undang-undang lain seperti UU Nomor 83 tahun 1959 tentang Penerbangan; UU Nomor 23 tahun 1959 tentang Keadaan Bahaya; UU Telekomunikasi; UU Nomor 41 tahun 1999 tentang Kehutanan; UU Perbankan, 
dan lain-lain.

Pada kelompok kedua, terdapat beberapa undang-undang yang menentukan korporasi sebagai subyek hukum pidana dan membebankan tanggungjawab pidana kepada korporasi pula, yaitu diantaranya UU Darurat Nomor 7 tahun 1955 tentang Penghapusan Tindak Pidana Ekonomi; UU 11/pnps tahun 1963 tentang Pemberantasan Kegiatan Subversi; UU tentang Nartkotika, UU Nomor 8 tahun 1995 tentang Pasar Modal, UU Nomor 23 tahun 1997 tentang Lingkungan Hidup; UU Nomor 5 tahun 1999 tentang Larangan Praktek Monopoli dan Persaingan Usaha Tidak Sehat; UU Perlindungan Konsumen; UU Nomor 20 Tahun 2001 tentang Pemberantasan Tindak Pidana Korupsi; dan beberapa peraturan lainnya.

Sementara dari beberapa undangundang yang menentukan korporasi sebagai subyek hukum pidana yang bisa dipertanggungjawabkan tersebut, ada beberapa undang-undang yang mengancam korporasi dengan pidana perampasan kemerdekaan, seperti UU Pemberantasa Tindak Pidana Ekonomi, UUPerlindungan Konsumen, UU Pemberantas Korupsi, UU Lingkungan Hidup.

Melihat fakta hukum di atas, Influencing view of society on crime and

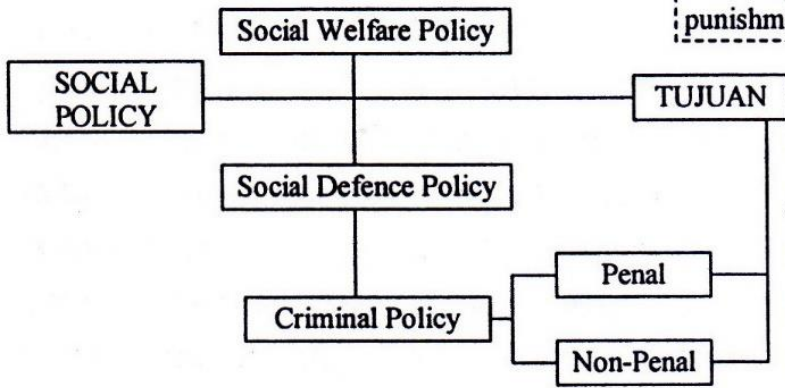

menunjukkan bahwa betapa kacaunya sistem hukum pidana Indonesia. Terlebih KUHP sebagai main system justru tidak mengakui korporasi sebagai subyek hukum pidana, sehingga otomatis pula tidak membebankan pertanggung jawaban pidana kepada korporasi. Kekacauan sistem itu menurut Abdul $\mathrm{Mu}$ 'id $^{23}$ jelas mempengaruhi sistem penegakan hukum pula. Karena seluruh peraturan perundangundangan di luar KUHP berinduk pada KUHP. Meskipun berdasarkan asas lex spesialis deregat lex generalis dapat saja KUHP disimpangi oleh ketentuan khusus yang diatur berdasarkan undang-undang di KUHP, namun tetap saja tidak akan maksimal, karena adanya hal-hal tertentu yang tetap merujuk pada KUHP. Misalnya, ketentuan pelaksanaan pidana denda yang tetap mengacu pada KUHP, dimana disebutkan bahwa apabila denda tidak dibayar, maka akan diganti dengan pidana kurungan. Dan tentu saja, pidana kurungan tidak akan bisa dikenakan kepada korporasi.

Pendapat Abdul Mu'id di atas jika dikaitkan dengan teori Marc Ancel bahwa jelas suatu sistem hukum akan mempengaruhi penegakan hukum dalam mencapai tujuan hukum ituendiri. Teori tersebut dpat digambarkan sebagai berikut: ${ }^{24}$

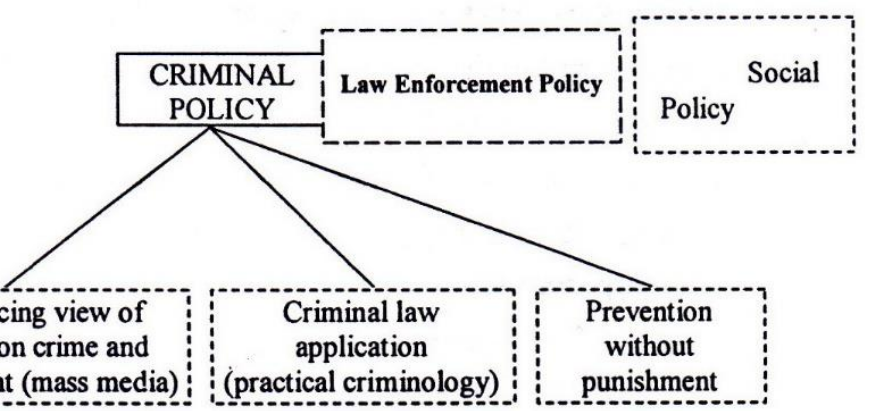

Dari skema di atas terlihat jelas bahwa kebijakan penanggulangan kejahatan (criminal policy) merupakan sub-sistem dari kebijakan sosial yang bisa dilakukan melalui dua model pendekatan yaitu pendekatan hukum pidana (penal) dan non-penal. Sementara itu, sehubungan dengan skema di atas, Hofnagels

${ }^{23}$ Abdul Mu'id (Kasi Pidsus Kejari Kota Malang), wawancara 12 Juni 2007

${ }^{24}$ Diskematiskan oleh Barda N. Arief (1996:3) dan dipertegas oleh Peter Hofnagels, The Other Side of Criminology, 1969, hal. 57 
juga memberikan skema terkait sebagai berikut:

Criminal policy atau kebijakan penanggulangan kejahatan menurut dua gambaran skema diatas jelas sangat menentukan dan ditentukan oleh law enforcement policy. Sehingga penegakan hukum terhadap pelaku kejahatan korporasi tidak akan efektif apabila kebijakan penanggulangan kejahatannya tidak progresif. Pertanyaan mendasar dalam hal ini adalah, bagaimana mungkin mengadili dan memberantas kejahatan korporasi apabila pelaku kejahatan korporasi tidak diakui sebagai subyek hukum pidana oleh hukum pidana itu sendiri?

Berbeda dengan Abdul Mu'id, salah satu anggota Satuan Reserse dan Kriminal Polresta Malang menyatakan bahwa KUHP sudah bagus mengatur tentang korporasi, dan sudah benar apabila KUHP tidak mengakui korporasi sebagai subyek hukum pidana yang harus dipertanggungjawabkan secara pidana. Menurutnya, hanya manusialah (pengurus korporasi atau pelaku aktual) saja ang ditindak. Hal itu akan lebih mudah dalam penegakan hukumnya.

Menurut Zulkarnain, hukum pidana positif yang berlaku di Indonesia memang masih kacau. Hal itu terkait dengan tidak adanya konsistensi pengaturan antara yang diatur dalam KUHP dengan pengaturan di luar KUHP. Dimana pengaturan korporasi di luar KUHP ada beberapa yang telah mengakui korporasi sebagai subyek hukum. Tetapi pengaturannya masih cenderung ragu-ragu, karena pengakuan undang-undang tersebut terhadap korporasi sebagai subyek hukum masih menafikan pertanggungjawaban korporasi dalam penegakan hukumnya. ${ }^{25}$

Apa yang disampikan oleh Zulkarnain

${ }^{25}$ Zulkarnain, Politik Hukum Pidana tentang Pemidanaan Korporasi di Indonesia, laporan penelitian, 2007, hal. 37 tersebut dibenarkan oleh Sunardi, ${ }^{26}$ informan yang pernah melakukan penelitian tentang pemidanaan korporasi dari segi normatif. Sunardi menyampaikan bahwa pengaturan pertanggung jawaan dan pemidanaan korporasi dalam sistem hukum pidana Indonesia masih mengacu pada paradigma yang menempatkan orang sebagai pelaku kejahatan. Sehingga meskipun jelas pelaku kejahatan adalah korporasi, tetapi yang dipertanggung jawabkan adalah orang alamiah.

\section{Kriminalisasi Kejahatan Korporasi dan Sistem Pertanggung Jawaban Korporasi dalam Hukum Pidana Indo- nesia}

Korporasi memang tidak diakui sebagai subyek hukum pidana dalam KUHP. Tetapi dalam hukum pidana positif di luar KUHP banyak yang mengatur korporasi yang diakui sebagai subyek hukum pidana. Misalnya Undang-undang Nomor 23 Tahun 1997 tentang Lingkungan Hidup, Undang-undang Nomor 20 Tahun 2001 tentang Pemberantasan Tindak Pidana Korupsi, Undang-undang Nomor 8 Tahun 1999 tentang Perlindungan Konsumen, Undang-undang tentang Pembentasan Tindak Pidana Pencucian Uang, Undang-undang Penyiaran, dan sebagainya. Bahkan sejak rezim pemerintahan yang anti tindak pidana ekonomi tahun 1955 telah mengeluarkan Undangundang Darurat nomor 7 tahun 1955 tentang Pengusutan dan Penuntutan Tindak Pidana Ekonbomi (UUTPE) telah dengan tegas mengakui Badan Hukum (in caso: Korporasi) sebagai subyek hukum pidana dan dapat dipertanggungjawabkan.

26 Wawancara, Fakultas Hukum Universitas Islam Malang, tanggal 20 Juli 2007 
Para pakar yang setuju menempatkan korporasi sebagai subyek hukum pidana menyatakan alasan-alasan sebagai berikut:

1. Pemidanaan pengurus saja tidak cukup untuk mengadakan represi terhadap delikdelik yang dilakukan oleh atau dengan suatu korporasi. Sehingga perlu pula pemidanaan korporasi, korporasi dan pengurus, atau pengurus saja.

2. Dalam kehidupan sosial ekonomi, korporasi semakin memainkan peranan yang penting pula.

3. Kalau hukum pidana hanya ditentukan pada segi perorangan, maka tujuan perlindaungan masyarakat itu tidak efektif, oleh karena itu tidak ada alasan untuk selalu menekan dan menentang dapat dipidananya korporasi.

4. Pemidanaan korporasi merupakan salah satu upaya untuk menghindarkan tindakan pemidanaan terhadap para pegawai korporasi itu sendiri."

Dalam penelitian Disertasi Sahuri, disebutkan bahwa untuk dapat mempertanggungjawabkan korporasi secara pidana ada empat persoalan pokok yang perlu diperhatikan, yaitu (1), masalah rumusan perbuatan yang dilarang; (2), masalalah penentuan kesalahan korporasi; (3) masalah penetapan sanksi terhadap korporasi; dan (4) sifat pertanggungjawaban korporasi. Untuk perumusan perbuatan yang dilarang dan pertanggungjawaban korporasi masih kurang jelas dalam menentukan siapa-siapa yang dapat melakukan tindak pidana dan korporasi yang bertanggungjawab. Dalam penentuan kesalahan korporasi, yang merupakan urat nadinya hukum pidana, sangat sulit karena kesalahan yang dilimpahkan kepada korporasi bukanlah korporasi secara pribadi, karena yang melakukan tindak pidana adalah orang/ pengurus. ${ }^{27}$

Begitu juga dengan sanksi pidana yang berhubungan dengan pertanggungjawaban korporasi, belum tertata secara jelas. Sedangkan sifat pertanggungjawaban korporasi dalam berbagai peraturan perundang-undangan tersebut bersifat mutlak jika orang yang melakukan tindak pidana tersebut mempunyai hubungan dengan korporasi atau mempunyai kedudukan fungsional. Sedanghkan bagaimana dengan alasan penghapusan pidana terhadap korporasi tidak ditemukan.

Dari hasil penelitian diatas, kemudian merekomendasikan bahwa sampai saat ini belum ada yurisprudensi tentang korporasi baik itu sebagai terdakwa maupun (apalagi) sebagai terpidana, sehingga perlu adanya penelitian terhadap perundang-undangan tersebut, hal apa saja yang menyebabkan undang-undang itu menjadi mandul. Selain itu, perlu diadakan penelitian terhadap kebijakan pemidanaan dan pertanggungjawaban korporasi dalam perspektif kebijakan hukum pidana Indonesia dengan harapan dapat mengungkap persoalanpersoalan hukum yang terkait dengan pertanggungjawaban korporasi.

Sunardi juga menyimpulkan bahwa pengaturan terhadap korporasi sebagai subyek tindak pidana harus jelas dan tegas dengan mencantumkan secara autentik dalam ketentuan umum KUHP yang sekarang sedang diperbaharui. Sehingga ketentuan di luar KUHP harus mengikutinya. ${ }^{28}$ Namun, Zulkarnain menilai bahwa pengaturan tentang sistem pertanggungjawaban korporasi baik dalam undang-undang khusus di luar KUHP maupun dalam Rancangan KUHP terbaru pun,

${ }^{27}$ Sahuri L., Pertanggungjawaban Korporasi dalam Perspektif Kebijakan Hukum Pidana Indonesia, Disertasi Ilmu Hukum, Universitas Airlangga, Surabaya, 2004

${ }^{28}$ Sunardi, Op. Cit. hal. 139-140 
tidak jelas dan komprehensif. Aspek empirik dan yuridis serta kepentingan publik terkait dengan pemidanaan korporasi dalam hal social welfare policy belum diperhatikan. ${ }^{29}$

Dari hasil penelitian ditemukan fakta bahwa sistem hukum pidana Indonesia masih belum mengakui sepenuhnya bahwa korporasi adalah subyek hukum yang bisa dipertanggungjawabkan. Meskipun ada beberapa produk kebijakan hukum pidana di luar KUHP yang mengatur pertanggungjawaban korporasi, namun sistem pertanggungjawaban korporasi yang dianut masih menggunakan doktrin vicarious liability. Hal tersebut sama halnya belum mengakui korporasi sebagai subyek hukum pidana. Namun kesimpulan akhir dari penelitian Zulkarnain di atas merekomendasikan adanya reformulasi kebijakan tentang sistem pertanggungjawaban pidana korporasi dan memasukkan rumusan tersebut dalam Kitab Undang-undang Hukum Pidana.

Pemidanaan merupakan salah satu sarana untuk menanggulangi masalah kejahatan korporasi (penal policy). Oleh karena itu, penggunaan sanksi yang berupa pidana terhadap kejahatan korporasi harus dipertimbangkan urgensi dan efektivitasnya. Karena pemidanaan bisa berfungsi sebaliknya dari yang diharapkan. Menurut Sudarto, ${ }^{30}$ suatu sanksi pidana akan menemui kegagalan dan mendatangkan kecemasan belaka. Apabila terlalu banyak menggunakan ancaman pidana dapat mengakibatkan devaluasi dari undangundang pidana.

Jeremy Bentham juga menyarankan bahwa pidana hendaknya jangan digunakan apabila groundless (tanpa dasar), needless (tidak sesuai kebutuhan), unprofitable (tidak menguntungkan), dan ineffective (tidak efektif).

\footnotetext{
${ }^{29}$ Zulkarnain, Op. Cit. hal. 38

${ }^{\text {so }}$ Dalam Setiyono, Op. Cit. hal. 177
}

Demikian juga dengan Parker, ia menyatakan bahwa pidana itu menjadi penjamin yang utama (prime guarantor) apabila digunakan secara cermat, hati-hati (profidently) dan secara manusiawi (humanly). Akan tetapi sebaliknya pidana bisa menjadi pengancam yang membahayakan (prime threatener) apabila digunakan secara indiscriminatly dan coercively.

Pidana pokok yang bisa dijatuhkan kepada korporasi hanyalah pidana denda (fine), tetapi apabila dijatuhkan sanksi berupa penutupan seluruh korporasi, maka pada dasarnya merupakan "corporate death penalty" (pidana mati bagi korporasi). Sedangkan sanksi berupa segala bentuk pembatasan terhadap aktivitas korproasi, maka sebenarnya mempunyai hakikat yang sama dengan pidana penjara atau kurungan, sehingga ada istilah "corporate imprisonment". Pidana tambahan dalam hal ini tetap bisa dijatuhkan. Bahkan pidana tambahan berupa pengumuman keputusan hakim, merupakan sanksi yang sangat ditakuti oleh korporasi. Setiyono kemudian menjelaskan bahwa sesuai dengan motif-motif kejahatan korporasi, maka sanksisanksi yang bersifat ekonomis dan administratif lebih sesuai diterapkan dalam pertanggungjawaban korporasi.

Namun, mengingat peranan korporasi sebagai pemberi kerja, maka penerapan sanksi (khususnya penutupan perusahaan) terhadap korporasi harus dipertimbangkan dengan cermat dan hati-hati. Hal ini sesuai dengan pendapat Muladi bahwa dampak pemberian sanksi terhadap korporasi dapat menimpa pada orang-orang yang tidak berdosa, seperti buruh, konsumen, pemegang saham dan sebagainya. Sebaliknya, apabila tindak pidana yang dilakukan sangat berat, maka di berbagai negara dipertimbangkan untuk menerapkan pengumuman keputusan hakim (adverse publicity) sebagai sanksi atas korporasi, sebab 
dampak yang ingin dicapai tidak hanya mempunyai financial impact, tetapi juga mempunyai non financial impact. ${ }^{31}$

Atas beberapa pertimbangan di atas, maka pidana penjara dan pidana mati sebagaimana diancamkan kepada subyek hukum pidana orang alamiah, tidak dapat dijatuhkan kepada korporasi. Sanksi yang bisa dijatuhkan kepada korporasi adalah: pidana denda, pidana tambahan, tindakan tata tertib, tindakan administratif, dan ganti rugi.

Kemudian mengenai pola pemidanaan dan pedoman pemidanaan dapat dipilih dari beberapa pola formulasi sanksi pidana, yaitu: formula tunggal, alternatif, kumulatif, dan kumulatif alternatif. Khusus terhadap kejahatan korporasi nampaknya lebih tepat apabila menggunakan formula kumulatif, karena selain korporasinya, pengurusnya juga patut dipersalahkan. Dan mengenai lamanya pemidanaan, mengingat besar dan luasnya kerugian akibat kejahatan korporasi, maka untuk pelaku tindak pidana korporasi dapat diterapkan formula minimum khusus.

Usaha dan kebijakan hukum untuk membuat peraturan hukum pidana yang baik pada hakikatnya tidak dapat terlepas dari tujuan penanggulangan kejahatan, sehingga kebijakan atau politik hukum pidana juga merupakan bagian dari politik kriminal yang identik dengan kebijakan penanggulangan kejahatan dalam hukum pidana. ${ }^{32}$ Dengan demikian, dapatlah disimpulkan bahwa pembaharuan hukum pidana merupakan bagian dari politik hukum pidana.

Makna dan hakikat pembaharuan hukum pidana berkaitan erat dengan latar belakang dan

${ }^{31}$ Muladi, Fungsionalisasi Hukum Pidana dalam Tindak Pidana Lingkungan Hidup, Makalah Seminar Nasional, Fakultas Hukum Universitas Udayana, Denpasar, 15 September 1990, hal. 7

${ }^{32}$ Barda N. Arief, 1996, Op. Cit. hal. 28 urgensi diadakannya pembaharuan hukum pidana itu sendiri, yang merupakan suatu upaya untuk melakukan reorientasi dan reformasi hukum pidana yang sesuai dengan nilai-nilai yang hidup dalam masyarakat Indonesia yang melandasi kebijakan sosial, kebijakan kriminal dan kebijakan penegakan hukum di Indonesia yaitu bahwa pembaharuan hukum pidana harus merupakan perwujudan dari perubahan dan pembaharuan berbagai aspek dan kabijakan yang melatarbelakanginya.

Pembaharuan hukum pidana pada hakikatnya dapat ditempuh dengan pendekatan yang berorientasi pada nilai (Value Oriented approach) dan pendekatan yang berorientasi pada kebijakan (Policy Oriented approach). Hal tersebut senada dengan apa yang dikemukakan oleh Bassiouni bahwa dalam melakukan pembaharuan hukum pidana diperlukan dua pendekatan yang terkait yaitu pendekatan yang berorientasi pada kebijakan yang lebih bersifat pragmatis dan rasional serta pendekatan yang berorientasi pada nilai. ${ }^{33}$

Terkait dengan pembaharuan hukum pidana tentang penanggulangan kejahatan korporasi, perlu dicatat bahwa dalam Rancangan KUHP Baru (KUHP Konsep) dalam penjelasan umum Buku I menyatakan bahwa:

"Mengingat kemajuan yang terjadi dalam bidang ekonomi dan perdagangan, subyek hukum pidana tidak dapat dibatasi lagi hanya pada manusia alamiah (natural person) tetapi mencakup pula manusia hukum (juridical person) yang lazim disebut korporasi. Dengan dianutnya. paham bahwa korporasi adalah subyek hukum, berarti korporasi sebagai bentuk badan usaha harus masih dimungkinkan pula pertanggung-jawaban

33 Hamdan, Politik Hukum Pidana. PT RadjaGrafindo Persada. Jakarta, 1997, hal. 29 
dipikul bersama oleh korporasi dan pengurus atau pengurus saja." 34

Dengan demikian, maka mengingat hal tersebut perlu pembaharuan kebijakan hukum pidana khususnya yang terkait dengan penanggulangan kejahatan korporasi dengan menjadikan korporasi sebagai subyek hukum pidana yang dapat dimintakan pertanggungjawaban.

Selain mengkaji terhadap peraturan hukum pidana positif yang berlaku, peneliti juga mengkaji konsep KUHP baru (RUUKUHP) yang merupakan ius constituendum. Dimana RUU KUHP ini telah dirancang (dengan berbagai perubahan-perubahannya) sejak tahun 1964 dan terakhir telah tersusun konsep KUHP tahun 2005. Pada konsep KUHP tahun 2004/2005 disebutkan pada Pasal 47 bahwa "Korporasi merupakan subyek tindak pidana." dan Pasal 48 menentukan bahwa "Tindak pidana dilakukan oleh korporasi apabila dilakukan oleh orang-orang yang bertindak untuk dan atas nama korporasi atau demi kepentingan korporasi, berdasarkan hubungan kerja atau berdasar hubungan lain, dalam lingkup usaha korporasi tersebut, baik sendiri-sendiri atau bersama-sama."

Menilik ketentuan dalam hukum pidana positif Indonesia dan rancangann KUHP yang sudah diuraikan di atas, nampaklah bahwa korporasi sudah diakui sebagai subyek hukum pidana menurut sistem peradilan pidana Indonesia meskipun KUHP masih tidak mengaturnya. Adapun sistem pertangungjawaban korporasi yang dianut menurut sistem hukum pidana adalah menentukan korporasi sebagai pembuat dan korporasi pula yang bertanggungjawab, dengan tetap memperhatikan pelaku fungsional yang

s4 Lihat Penjelasan Umum RUU KUHP 1999/2000 Buku Kesatu angka 2 didasarkan pada doktrin identivication theory. Doktrin ini memandang bahwa perbuatan/ delik dan kesalahan/sikap batin pejabat senior dipandang sebagai perbuatan dan sikap batin perusahaan. Unsur-unsur tindak pidana dapat dikumpulkandari perbuatan dari sikap batin dari beberapa pejabat senior.

Pada konteks ini, Sutan Remy Sjahdeiny mengemukanan doctrine of delegation yang bisa dijadikan dasar pembenar untuk dapat membebankan pertanggungjawaban pidana yang dilakukan oleh pegawai kepada korporasi. Menurut doktrin ini, alasan untuk dapat membebankan pertanggung jawaban pidana kepada korporasi adalah adanya pendelegasian wewenang dari seseorang kepada orang lain untuk melaksanakan kewenangan yang dimilikinya. Nampaknya konsep KUHP juga menjadikan doktrin ini sebagai rujukan dalam menerapkan pertanggung jawaban pidana bagi korporasi. $^{35}$

\section{E. Konsepsi Penal Policy dalam} Penanggulangan Kejahatan Korporasi

Secara umum dan teoritik penyebab kejahatan korporasi bisa dilihat dari berbagai aspek sistem hukum, ${ }^{36}$ yaitu:

a. Jika dikaji dari legal substancy maka kejahatan korporasi sangat berkorelasi signifikan dengan tidak adanya kebijakan legislasi (sistem hukum pidana) Indonesia yang mengatur kejahatan korporasi secara tegas. Sistem pemidanaan dan pertanggungjawaban pidana yang dianut dalam hukum pidana positif Indonesia masih

${ }^{35}$ Sutan Remy Sjahdeiny, Pertanggung jawban Pidana Korporasi, Grafittipress. Jakarta, 2006, hal. 97

${ }^{36}$ Friedman menyimpulkan bahwa hokum sebagai system terdiri dari tiga subsistem yaitu, legal substancy; legal structure dan legal culture yang ketiganya saling terkait dan menentukan. 
menitikberatkan pada orang secara lamiah (naturlijke person). Sehingga kejahatan korporasi masih belum dianggap sebagai 'kejahatan yang serius'.

b. Dari konteks legal structure nampaknya memperlihatkan ketidakpahamam para penegak hukum terhadap aspek-aspek kejahatan korporasi dan pertanggungjawaban pidana bagi korporasi.

c. Dilihat dari aspek legal culture menunjukkan bahwa masalah corporate social responsibility (CSR) masih belum menjadi bagian integral dari korporasi yang ada di Indonesia.

Senada dengan itu, maka terkait dengan faktor kriminogen dari kejahatan korporasi dapat penulis sajikan beberapa hasil focus group discussion sebagai berikut:

1. Kejahatan korporasi adalah extra ordinary crime yang penanggulangannya harus ula dilakukan secara extra ordinary;

2. Memberantas kejahatan korporasi tidak akan efektif apabila tidak didasarkan pada akar kriminogennya. Oleh kerena itu, faktor kriminogen harus ditelusuri secara sermat dan komprehensif;

3. Dilihat dari segi hukumnya, maka persoalan kejahatan korporasi tidak lepas dari berbagai masalah yang menghinggapi sistem hukum (substansi, struktur, dan budaya);

4. Dari aspek substansi, jelas akar permsalahannya adalah terletak pada masih kacaunya tatan hukum pidana positif Indonesia yang masih tidak mengakui korporasi sebagai subyek hukum pidana yang dapat dipertanggungjawabkan secara pidana. Pengaturan di luar KUHP juga tidak efektif karena dalam penegakkannya juga masih menggunakan asas umum dalam KUHP dan prinsip-prinsip prosedural sesuai KUHAP, yang dengan tegas tidak mencantukan korporasi sebagai subyek hukum yang bisa dihadapkan diperadilan pidana tanpa menggantikannya kepada persona alamiah sebagai pengurus korporasi sebagaimana doktrin vicarius liability.

5. Coprporate Social Responsibility (CSR) dari korporasi masih lemah bahkan tidak ada.

6. Dari aapek struktur, ternyata penegak hukum di Indonesia masih banyak yang belum paham tentang konsep sistm pertanggungjawaban pidana korporasi. Sehingga, meskipun sudah ada ketentuan di luar KUHP yang mengatur tentang dapat dipertanggungjawabkannya korporasi, tetap saja tidak mampu mengeliminir potensi kejahatan korporasi.

Dengan demikian, maka dilihat dari sudut pandang politik kriminal, maka masalah strategis yang justru harus segera diselesaikan adalah masalah-masalah kebijakan legislasi (criminal policy). Hal ini menunjukkan bahwa penanganan terhadap pemberantasan kondisikondisi yang kriminogen menjadi titik kunci dalam penanggulangan tindak pidana dari sudut politik kriminal. Hal ini senada dengan resolusi PBB menganai crime trends and crime prevention strategies bahwa strategi pencegahan kejahatan harus didasarkan pada penghapusan sebab-sebab dan kondisi-kondisi yang menimbulkan kejahatan (crime prevention strategies should be based upon the elimination of causes and conditions giving rise to crime), yaitu masalah tidak adanya kebijakan legislasi yang integratif dengan kebijakan sosial dan kebijakan penegakan hukmnya.

Hal terpenting dalam masalah kebijakan kriminal ini adalah bagaimana mengintegrasikan strategi penanggulangan kejahatan (penal dan non-penal) ini dengan kebijakan sosial lainnya. Karena tanpa kebijakan yang integratif, akan melhirkan kriminogen baru dari kejahatan korporasi. Bahkan kebijakan 
penanggulangannya kejahatanpun menjadi kriminogen.

\section{PENUTUP}

Maraknya kejahatan korporasi bukanlah suatu fakta hukum yang muncul begitu saja tanpa ada faktor kriminogennya. Namun faktor kriminogen dari kejahatan korporasi ternyata berbeda dari kejahatan pada umumnya yang lebih menekankan pada fektor empirik. Sementara kejahatan korporasi banyak dipengaruhi oleh lemahnya legal substancy dalam mengatur kejahatan korporasi.

Beberapa faktor tersebut sangat berkorelasi signifikan dengan kebijakan legislasi tentang sistem pertanggungjawaban korporasi di Indonesia. Oleh karena itu, menanggulangi kejahatan korporasi harus menitikberatkan pada pembaharuan hukum pidana tentang kriminalisasi dan pemidanaan pelaku kejahatan korporasi. Akan tetapi tidak cukup demikian. Seluruh kebijakan legislasi yang akan dibuat harus integratif dan tidak saling berpotensi kriminogen.

$$
-000-
$$

\section{DAFTAR PUSTAKA}

Amrullah, Arief. 2003. Politik Hukum Pidana dalam Rangka Perlindungan Korban Kejahatan Ekonomi di Bidang Perbankan, Bayumedia Publishing, Malang

Ancel, Marc. 1965. Social Defence: A Modern Approach to Criminal Problems, Routledge \& Kegan Paul, London

Arief, Barda Nawawi. 1996. Bunga Rampai Kebijakan Hukum Pidana, Citra Aditya Bakti, Bandung

Assiddiqie, Jimly. 1995. Pembaharuan hukum Pidana Indonesia, Angkasa, Bandung

Atmasasmita, Romli. 2000. Perbandingan Hukum Pidana, Mandar Maju, Bandung

Dirdjosisworo, Seodjono. 1991. Hukum Pidana Indonesia dan Gelagat Kriminalitas Masyarakat Pasca Industri, Pidato Pengukuhan Jabatan Guru Besar pada FH. UNPAR, Bandung

Gillies, Peter. 1990. Criminal Law, The Law Book Company Limited, Sidney

Hamdan. 1997. Politik Hukum Pidana. PT RadjaGrafindo Persada. Jakarta

Hatrik, Hamzah. 1996. Asas Pertanggungjawaban Korporasi dai hokum Pidana Indonesia: Strict Liablity dan Vicarious Liability, Raja Grafindo Persada, Jakarta

Hofnagels, G.P. 1969. The Other Side of Criminology

Klitgaard, Robert, Ronald Maclean-Abaroa dan Lindsey Parris. 2002. Penuntut Pemberantasan Korupsi dalam Pemerintahan Daerah. Yayasan Obor Indonesia. Jakarta

Muladi . 1992. Bunga Rampai Hukum Pidana. Penerbit Alumni. Bandung

dan Barda Nawawi Arief, 1992. Teoriteori dan Kebijakan Pidana, Penerbit Alumni, Bandung

dan Dwidja Priyatno. 1991. Pertanggungjawaban Korporasi dalam Hukum Pidana, Sekolah Tinggi Ilmu Hukum Bandung, Bandung

. 2002. Demokratrisasi, Hak Asasi Manusia, dan Reformasi Hukum di In- 
donesia, The Habibie Center, Jakarta 1990. Fungsionalisasi Hukum Pidana dalam Tindak Pidana Lingkungan Hidup, Makalah Seminar Nasional, Fakultas Hukum Universitas Udayana, Denpasar, 15 September 1990

2004. Pertangungjawaban Korporasi dalam Hukum Pidana (Corporate Criminal Liability), Makalah pada Seminar Nasional tentang Aspek Pertanggungjawaban Pidana dalam Kebijakan Publik dari Tindak Pidana Korupsi, Kejaksaan Agung RI dan FH UNDIP, Semarang 6-7 Mei 2004

Poernomo, Bambang. 2004. Prospek Perkembangan Sanksi Pidana dalam Lingkup Asas-asas Hukum Pidana Nasional di Indonesia, Makalah pada Seminar tentang Asas-asas Hukum Pidana Nasional, Semarang 26-27 April 2004.

Priyatno, Dwidja. 2004. Kebijakan Legislasi tentang Sistem Pertanggungjawaban Pidana Korporasi di Indonesia, CV. Utomo, Bandung

.2005. Rancangan KUHP Tak Mengatur Sanksi Korporasi, dalam http:// www.pikiran-rakyat.com/cetak/2005/ 1005/01/1102.htm tanggal 26 Oktober 2005

. 1991. Suatu Tinjauan Terhadap Pertanggungjawaban Korporasi dalam Hukum Pidana dan Prospeknya, Tesis Program Pascasarjana UNDIP, Semarang

Prodjodikoro, Wirjono. 1986. Azas-azas Hukum Pidana Indonesia, Eresco, Bandung

Rahardjo, Satjipto. 1986. Ilmu Hukum, Alumni, Bandung

Ramelan. 2004. Pertanggungjawaban Korporasi dalam Hukum Pidana, Makalah pada Seminar Nasional tentang Aspek Pertanggungjawaban Pidana dalam Kebijakan Publik dari Tindak Pidana Korupsi, Kejaksaan Agung RI dan FH UNDIP, Semarang 6-7 Mei 2004

Reid, S.T. 1985. Crime and Criminology, Hola, Reindard \& Winston

Reksodiputro, Mardjono. 1994. Hak Asasi Manusia dalam Sistem Peradilan Pidana, Pusat Pelayanan Keadilan dan Pengabdian Hukum, Universitas Indonesia, Jakarta
Sahuri L. 2004. Pertanggungjawaban Korporasi dalam Perspektif Kebijakan Hukum Pidana Indonesia, Disertasi Ilmu Hukum, Universitas Airlangga, Surabaya

Saleh, Roeslan. 1983. Perbuatan Pidana dan Pertanggungjawaban Pidana: Dua Pengertian Dasar dalam Hukum Pidana, Aksara Baru, Jakarta

Santosa, Mas Ahmad. dkk. 1998. Penerapan Asas Tanggung Jawab Mutlak (Strict Liablity) di Bidang Lingkungan Hidup, Indonesia Center for Environmental Law (ICEL), Jakarta

Schafmeister, N. Keijzer dan P.H. Sutorius. 1995. Hukum Pidana, Editor Terjemahan J.E. Sahetapy, Konsorsium Ilmu Hukum Departemen Pendidikan dan Kebudayaan dan Liberty, Yogyakarta

Setiyono. 2003. Kejahatan Korporasi, Bayumedia Publishing, Malang

Sjahdeini, Sutan Remy. 2006. Pertanggungjawban Pidana Korporasi, Grafittipress. Jakarta

Sudarto, 1983. Hukum Pidana dan Perkembangan Masyarakat: Kajian terhadap Pembaharuan Hukum Pidana, Sinar Baru, Bandung

Sudarto. 1988. Hukum Pidana 1, Badan Penyediaan Bahan-bahan Kuliah UNDIP, Semarang

Sunardi dan Fanny Tanuwijaya. 2002. Pidana Perampasan Kemerdekaan bagi Korporasi, Universitas Islam Malang, Malang

Susanto, I.S. 1995. Kejahatan Korporasi, Balai Penerbitan Universitas Diponegoro, Semarang . 1998. Tinjauan Kriminologis tentang Kejahatan Ekonomi, Makalah pada Penataran Hukum Pidana dan Kriminologi, UNDIP, Semarang 23-30 Nopember 1998

Weda, Made Darma. 1993. Beberapa Catatan tentang Kejahatan Korporasi, Makalah pada Seminar Nasional Viktimologi III, Fakultas Hukum Universitas Airlangga Surabaya, 20-21 Desember 1993

Zulkarnain. 2007. Politik Hukum Pidana tentang Pemidanaan Korporasi di Indonesia. Laporan Penelitian Universitas Widyagama. Malang 